\title{
Transforming South Africa's low-income housing projects through backyard dwellings: Intersections with households and the State in Alexandra, Johannesburg
}

\author{
Yasmin Shapurjee ${ }^{1 *}$ \\ Sarah Charlton ${ }^{2}$
}

\begin{abstract}
South Africa's 'housing programme' transfers a fully-funded serviced site and house to qualifying beneficiaries with aims of progressively addressing poverty through homeownership. Despite delivering close to 3 million houses since 1994, informal housing persists, featuring even in some of these new neighbourhoods. This paper focuses on the intersection between a particular mode of informal housing, backyard dwellings, and state-subsidised low-income housing projects. Backyard dwellings arguably contradict state housing objectives by symbolising informality and disorder; a symptom of inadequacy that the housing programme strives to overcome. We consider first the views and experiences of landlords (owners of state-subsided houses) and tenants (occupiers of privately-provided backyard dwellings) in a section of Alexandra, Johannesburg. We then reflect on the potential of backyard accommodation within postapartheid housing delivery, arguing that despite challenges, the phenomenon of planned, state-led infrastructure generating secondary accommodation represents an opportunity rather than an example of failed modernity. South Africa's backyard dwellings resonate with similar forms of self-funded and managed rental stock across the global South. As a quick, flexible and regenerative housing asset, cumulative acceptance of such rental markets is necessary - along with viewing the driving actors as astute innovators in shelter and livelihood provision.
\end{abstract}

Key Words: Alexandra, backyard dwelling, Johannesburg, low-income housing, RDP, rental housing, state infrastructure, South Africa

\footnotetext{
${ }^{1}$ CSIR Built Environment, Planning Support Systems. PO Box 395, Pretoria 0001, South Africa Email: YShapurjee@csir.co.za

Tel: (012) 8412044

Fax: (012) 8414036

${ }^{*}$ Corresponding author

${ }^{2}$ School of Architecture and Planning, University of the Witwatersrand. Private Bag X3, Wits, Johannesburg 2050, South Africa

Email: Sarah.Charlton@wits.ac.za

Tel: (011) 7177717
} 


\section{Introduction}

Informal housing ${ }^{1}$ in cities of the South takes many forms beyond that of informal settlements. These include multiple rental housing configurations: sub-divided rooms in inner city areas (see for example Beijaard, 1986; Ha, 2002; Poulsen, 2010); rooms and flats in multi-storey tenements (Huchzermeyer, 2007); rooms in various low-income settlements (Gilbert and Varley, 1989; Rakodi, 1995; Kumar, 1996a, 2003); sub-let units on rented land (Furedy, 1982; Roy, 1983, cited in Kumar, 1989, p.76); and tenant-built units in the backyards of dwellings (see Gilbert et al., 1997; Crankshaw et al., 2000).

Informal rental tenure is regarded as an 'essential option for the urban poor in developing countries' (UN-HABITAT, 2003, p. i) and in need of policy support (Watson, 1994; Gilbert, 2008; Carey 2009; UN-HABITAT, 2011), although limited policy 'uptake' of research remains a major concern (see Kumar, 2011). Housing policy in developing countries has tended almost exclusively towards homeownership (see Gilbert, 2008). Yet the informal rental market houses many poor households in the global South (Rakodi, 1995; Kumar, 1996a; UN-HABITAT, 2003; Watson, 2009) and proves to suit diverse household needs in contexts of rapid urbanization, lingering income-poverty, and limited state housing resources.

This paper considers the intersection between formal and informal housing in South Africa, focusing on backyard dwellings which have arisen in a state-subsidised lowincome 'Reconstruction and Development Programme' (RDP) ${ }^{2}$ housing project. Juxtaposing formal with informal, planned with unplanned, RDP backyard dwellings contest formal, 'normal' housing settlements and accepted beneficiary behaviour (Robins, 2002). The emergence of informal housing in RDP settlements designed to improve poor quality and informal living conditions is termed by Lemanski (2009, p. 472) "augmented informality"; attributed partly to 'failures' of South Africa's 'formal' housing policies that prioritise homeownership over rental housing. 
This paper builds on Lemanski's (2009) in-depth research in Cape Town's Westlake village RDP settlement, and motivates that instead of being viewed as a corruption of modernity and order, backyard dwellings can be viewed differently. The paper illustrates the human value of backyard dwellings for a small group of landlords and tenants living in Extension 8, Alexandra in Johannesburg - foregrounding the diverse roles the accommodation serves in their lives. These lived experiences further prompt a reflection on broader issues related to the RDP-backyard phenomenon. The two scales of analysis arise from considering an example of the state's mass housing programme, which individual housing beneficiaries have adapted in unintended ways.

We first contextualise South Africa's backyard dwellings in literature on informal rental housing in the South. We describe the Alexandra case study, and discuss the largely favourable experiences of these landlords and tenants who interact with RDP backyard dwellings. We consider how these local perspectives offer potential for the state, arguing that backyard dwellings offer a useful supply of household-managed cheap rental accommodation; that these dwellings gear private investment from state investment; and that backyard dwellings in formal housing developments can improve settlement-level urban performance. We conclude by re-iterating calls for innovation in supporting cheap rental accommodation supply in poorer contexts (see Watson, 1994; UN-HABITAT, 2003; Gilbert, 2008; Gardner, 2010; Poulsen, 2010; Kumar, 2011), particularly where this can be linked to government investment.

\section{Characterising backyard dwellings}

Backyard accommodation involves the co-habitation of landlord and tenant on the same plot, albeit in different dwellings. Whilst the nature of co-habitation varies across different contexts, related patterns of this type of housing as summarised by UN-HABITAT (UNHABITAT, 2003, p. 44) include:

...the 'rentyards' of the Caribbean, [Fass,1987; Clarke and Ward,1978; Potter, 1995] ...the 'lost cities' of Mexico [Ward, 1976] and their equivalents in Lima,[Dietz, 1981] [as well as] 
the bustees of Calcutta[Roy, 1983] ... the land rental slum settlements of Bangkok[Angel and Pornchokchai, 1989; Pornchokchai, 1992, p. 59; Yap and Wandeler, 1990]...

The closest counterpart to South Africa's backyard dwellings seem to be the allegados of Santiago, Chile, occupied by relatives of those in the main dwelling who oftentimes do not pay monetary rent (see Crankshaw et al., 2000 for a comparative study). In South Africa, tenants usually pay rent and in most cases also organise the building of their backyard dwellings (Gilbert et al., 1997, Watson and McCarthy, 1998; Morange, 2002; Lemanski, 2009).

Backyard dwellings offer benefits for poorer migrants to enter urban systems, thereby supporting economic livelihoods and offering quick access to cheap, flexible housing, which may be relatively close to employment opportunities and amenities (Gilbert et al., 1997; Watson and McCarthy, 1998; Crankshaw et al., 2000; Morange, 2002). Whilst landlords benefit from rental, most operate as 'subsistence landlords' (see Kumar, 1996b) and are not profit-maximizers but like their tenants, may also be 'cash-poor' across various South African settlements (Gordon and Nell, 2006; Lemanski, 2009³). At times backyard dwellings can also provide accommodation for family members rather than paying tenants (Lemanski, 2009), although this trend appears less common.

Backyard dwellings exist on a significant scale in South Africa. In the most populous province of Gauteng where our case study is, $28 \%$ of the rental market is made up of 'shacks' and 'backyard shack dwellings' (General Household Survey 2007 cited in Social Housing Foundation, 2008, p. 5). In Johannesburg, estimates of backyard dwelling counts hover around 270000 (City of Johannesburg, 2012), many of these occurring in older apartheid-era townships.

Below we discuss the case study of Extension 8, Alexandra which offers an example of the specific RDP-backyard phenomenon within an area of Johannesburg undergoing urban renewal. 


\section{Case study: Extension 8 in Alexandra, Johannesburg}

Alexandra ('Alex') is a dense impoverished urban area located some $12 \mathrm{~km}$ northeast of Johannesburg's Central Business District but within 3kms of the wealthy, commercial, retail and residential node of Sandton (see Fig. 1). This location near high value property and economic activity is relatively unusual for low-income settlements in South Africa.

\section{[Insert Figure 1]}

Alexandra has a particular history of freehold property rights ${ }^{4}$ for African black residents. Despite efforts by the Apartheid government to reduce population size, control migration and expropriate property, the area grew as a prominent labour pool for Johannesburg. Alexandra's history and location means that the 'business of rental' is significant - in 2005 approximately $70 \%$ of households in Alexandra resided in backyard 'shacks' in the yards of old houses (ARP, 2005).

Alexandra exhibits severe overcrowding, infrastructure deficiencies and expanding poverty and unemployment. The Alexandra Renewal Project (ARP) - a state-sponsored area-based urban renewal initiative launched in 2001 - aims to improve the overall living environment, through infrastructure upgrades and housing construction amongst other things. Alongside RDP housing delivery, the ARP has supported a limited amount of rental accommodation in pilot projects ${ }^{5}$.

\subsection{The Extension 8 Housing Project}

The Extension 8 RDP housing project, completed in 2005, is on the Far East Bank ${ }^{6}$ of Alexandra and consists of 181 detached RDP units. Built to accommodate households relocated from shacks ${ }^{7}$ in other parts of Alexandra, the settlement comprises one-roomed $36 \mathrm{~m}^{2}$ RDP houses on $200 \mathrm{~m}^{2}$ plots. Subsequently, backyard dwellings sprung up in the neighbourhood. More recent RDP projects in Alexandra have average plot sizes of $80 \mathrm{~m}^{2}$, aiming for greater land-use efficiency, whilst also discouraging private backyard dwelling construction (N. Letter, Deputy Director: ARP, personal communication, 2010). Backyard dwellings are perceived by the ARP to undermine urban renewal initiatives through 
overcrowding, perpetuating poor housing quality and appearance, and burdening water, electricity and sanitation capacity (N. Letter, Deputy Director: ARP, personal communication, 2010).

\subsection{Data and Methodology}

For a perspective from users of both RDP and backyard accommodation, qualitative, semi-structured interviews with landlords and tenants were conducted in Extension 8 in 2010, probing interviewees' relationships with backyard dwellings and the role this accommodation plays in their lives. Relationships between landlords and tenants were not a focus here, and this is an important area for further research.

A total of 18 respondents ${ }^{8}$ (8 landlords and 10 tenants) were interviewed, with the assistance of a translator ${ }^{9}$ who lives locally. Interviews were captured as a series of biographies ${ }^{10}$ to convey findings in a more personal manner. Whilst the sample size is small we have used the qualitative depth to derive detailed insight to support a reflexive discussion with related literature.

\section{Household relationships with backyard dwellings in Extension 8}

Findings from the case study are organised into four sections: first, landlord and tenant profiles, second how backyard accommodation is produced, third the function the accommodation performs, and fourth landlord and tenant perceptions of the accommodation. In the discussion below, extracts from selected respondent biographies illustrate diverse household relationships with backyard dwellings.

\subsection{Landlord and tenant profiles}

Findings in Extension 8 conform to trends of younger, smaller tenant households than those of landlords (Gilbert, 1983; Gordon and Nell, 2006; Bank, 2007). Most tenants interviewed are recent migrants to Gauteng, with Alexandra representing their 'gateway' to Johannesburg, and for some, their gateway to South Africa. 
In comparison with landlords, tenants are perceived to have greater income security with most respondents having permanent jobs and slightly higher incomes. But the generally low incomes of both parties suggests co-dependency similar to that observed elsewhere, such as in self-help settlements in Bogota, Columbia, Valencia in Venezuela, and Mexico City, Mexico (Gilbert, 1983); in India's Surat and Bangalore (Kumar, 2003) and also in some South African townships (Gordon and Nell, 2006).

Tenant respondents indicate their accommodation is relatively flexible, allowing them to respond to employment opportunities elsewhere. However, constraints at the household, settlement and city scales restrict the extent of real choice related to this accommodation (see Gilbert (1983) for a description of the 'choice or constraint' thesis). In Extension 8, constraints include very few affordable, formally acceptable accommodation alternatives in Alexandra, in part because a number of tenant households also do not meet eligibility criteria $^{11}$ for state-subsidised housing.

A comparison of life-cycles and life-stages of landlord and tenants respondents suggests different priorities. For landlords, backyard dwellings predominantly reflect a need for household income to support a larger family. For tenants, it reflects choice and an ability to change their housing circumstances.

\subsection{Types and delivery of backyard dwellings}

Three different types of backyard dwellings (see Figures 2, 3 and 4) were encountered in Extension 8: the shack, the 'izozo' and the room, each varying in material quality and rentals charged. Table 1 summarises these differences, showing the high cost and quality of rooms compared to shacks and izozos.

\section{[Insert Table 1]}

\section{[Insert Figures 2a, 2b; 3a, 3b and $4 a, 4 b]$}

Typologies described above conform to those found in other South African townships (see Gordon and Nell, 2006) with rooms generally constructed by landlords, whilst others 
are predominantly built or assembled by tenants. In Extension 8, landlord Mr D has constructed both rooms and shacks, thereby 'building' an income through backyard dwellings:

Mr D (aged 30) came to Alexandra in 2005, first staying in a shack in $20^{\text {th }}$ Avenue before coming to his father's RDP house in Extension 8. With his father having moved back to their rural home in Limpopo, Mr D presently stays with his mother, wife and their 3-year-old child. A labourer in the construction industry, Mr D has added two rooms to his original RDP home. He has also built seven backyard dwellings, a combination of shacks and rooms. Mr D's monthly rental income alone amounts to $R 2500$ (roughly \$300) which he uses to support his parents and younger sisters. He plans to build an additional five backyard rooms to make a total of twelve backyard dwellings.

Mr D's reinvestment of rental income into housing improvements is significant, facilitated by his building skills and access to building materials from his job. Other landlords interviewed also hoped to improve their backyard dwellings if they could access the financial means to do so.

\subsection{Function of backyard rental for landlord and tenant}

\subsubsection{Landlord Perspectives}

Interviews with RDP owners confirm a dominant financial motivation for having backyard dwellings. Landlords are either unemployed, temporarily out of work or involved in intermittent casual work. Particularly in female-headed households, social roles and responsibilities limit opportunities for stable employment and encourage rental income generation as a reaction to income poverty:

'I stay all by myself and have to look after this little one [pointing to sick grandchild]. You see because of this I am not working. I am not even a pensioner...' (Mrs L, 21/06/2010)

Mrs L's primary source of income derives from her grandchild's disability grant, much of which is used to cover medical and household consumption costs. This type of gendered vulnerability is noted elsewhere in South African townships (Gilbert et al., 1997; Crankshaw et al., 2000; Lemanski, 2009) where women-headed households typically act as landlords in the absence of male breadwinners or in contexts where their spouses are working. 
At the time of the research in 2010 , job insecurity was highlighted by RDP households, despite Alexandra's central location. 3 out of 8 landlords recounted how they or their spouses lost their job within the last two years. Backyard dwellings typically emerged in Extension 8 during 2008/2009, possibly reflecting a link to the economic recession although this link is untested.

In two cases amongst respondents, landlords supplied backyard dwellings not for rental income but to accommodate family members and to gain privacy. Family members are expected to reciprocate by keeping the yard and outside toilet clean. Mrs $\mathrm{K}$ explains her motivation for developing backyard rooms: 'to house the next generation':

Mrs. $K$ (aged 46) is building outside rooms to accommodate her four children in the future. $A$ native of Alexandra, Mrs. $K$ sees the township as an exciting place to live, work and socialize. By deciding to give her sons their own rooms, she feels that she is empowering them to gain independence whilst remaining in the area. So far Mrs. $K$ has built three 'proper' rooms -built of cement and brick to avoid the unsafe and unhealthy conditions in shacks that she has personally experienced in the past. She hopes that her eldest son will soon be able to move into one of the rooms.

\subsubsection{Tenant Perspectives}

Tenants interviewed indicate a sense of safety from being 'under the protection' of landlords. RDP environments perceptibly safer than shack settlements in Old Alexandra as $\mathrm{Mr} \mathrm{G}$, a 32 year old Zimbabwean tenant, explains:

Where I was staying [before], it was not safe...a lot of criminals all around us...and I was being robbed twice......that's why I come here [to Extension 8] ... The place is so good and it is quiet.' (Mr G, 10/06/2010)

Backyard dwellings also provide landlords some comfort around crime prevention. AC explains:

'Most of the time you find you have to go to work...like outside Johannesburg.... At least now it's helpful because... there are people in the yard. So it's not easy for somebody to come in and do whatever he wants in my yard. (A.C, 23/06/2010)

A further three foreign tenants interviewed have experienced xenophobic threats of violence in Alexandra. Like Nyasha (below), for the others, relocation to Extension 8 was influenced by their by previously insecure living environments. Extension 8 yards provide a refuge for these households, with tenants 'hidden' behind formal housing: 
Nyasha (aged 27) was a teacher in Bulawayo, Zimbabwe before moving to Alexandra to improve her economic prospects. During 2007 and 2008 she lived in a backyard shack with her siblings in $4^{\text {th }}$ Avenue, and felt comfortable and safe. But the violent xenophobic events that unfolded in 2008 scared her. When the violence eventually subsided, Nyasha looked for a safer place to stay with her boyfriend. Friends recommended Extension 8. Nyasha feels she was in effect pushed out of Old Alexandra, but is nevertheless content with 'backyard living' in Extension 8: she feels that she and her boyfriend are out of direct harm's way - being sheltered from crime by their landlord.

Whilst Nyasha recounts a generally positive experience, the effects of accommodating immigrants (whether illegal or legal) in Extension 8 backyards were not probed in depth, and anecdotes of tensions amongst some RDP neighbours invite further investigation into backyard tenants' future security in a context such as Alexandra.

\subsection{Perception of backyard dwellings}

Despite positive functions of backyard dwellings, most landlords interviewed felt the phenomenon was not ideal, despite feeling compelled to let yard space because of financial insecurity.

'Everybody like to stay alone with your own yard...it's not good to keep people in the backyard. But because of hungry, because you don't have money...you have to do it.' (Mrs L, 21/06/2010)

Landlords suggest that some of their RDP neighbours are unhappy with backyard dwellings as they fear the area is being 'invaded' by shacks. They also have fire concerns as some shacks are made of flammable materials. But Mrs $L$ feels that having backyard dwellings is acceptable mainly because so many other RDP owners are doing the same:

'Some of them - they've got [backyard dwellings]. A lot of them, they've got. But the others - they haven't got... Of course they complain that they don't like this place. It just looks like the old location [Apartheid township] with the 'mekuku' [informal shacks] whatever... but I just follow the others [who do have backyard dwellings].' (Mrs L, 21/06/2010)

Two tenants interviewed (one living in a backyard room and one living in an izozo) also hold negative attitudes towards backyard shacks.

'The rooms are better but the shacks... I don't like the shack....The yard [is] disorganised ... it feels [more] comfortable when they stay in the rooms than in shacks.' (Nthabiseng, 23/06/2010)

'I don't think it's a good idea. Maybe if people could like build backyard proper rooms...you know like... in Soweto you see how the rooms are... maybe it could be much better.' (Nyasha, 23/06/2010) 
The mixed views of RDP owners, tenants and neighbours highlight some tensions around RDP-backyard accommodation. Although landlords are sympathetic to those looking for a place to stay, and are motivated by immediate rental income needs, the housing outcome is not wholly desirable to neighbourhood residents.

Despite the physical discomforts (small size, poor thermal performance) noted by most tenants (except those living in backyard rooms), backyard accommodation in Extension 8 is nevertheless considered to offer better living conditions than respondents experienced before - a step-up from congested, poorly serviced and dilapidated shack settlements, as one example. Although not probed in detail in this study, the impression gained of landlord-tenant relationships concurs with descriptions of a mutually beneficial, largely non-exploitative arrangement (Crankshaw et al., 2000; Morange, 2002; Bank, 2007) at least in more recent times as Lemanski (2009) notes.

Overall the experiences of landlord and tenant respondents are generally positive. For landlords backyard dwellings are an important source of income or offer extra space for family members. For many tenants the accommodation offers improved quality living, a better sense of safety and 'room for manoeuvre'13. Noting variance in dwelling qualities, some see backyard shacks in particular as detracting from urban quality and dignity, whilst others see building decent rooms as a way of overcoming limitations of their state funded house.

\section{The potential of backyard dwellings for the State}

From reflecting on the financial and experiential benefits of RDP backyard dwellings in Extension 8, we now discuss what the phenomenon potentially offers the state. But we also note some difficulties that need to be overcome or at least confronted.

As Extension 8 shows, backyard accommodation varies considerably in quality and comfort. Despite this, it provides much needed cheap accommodation that other providers cannot deliver easily: low in capital cost to the developer, and low in rental 
costs for the user too. It can also be delivered very rapidly like other private small-scale rental accommodation units (Gardner, 2010).

But as Old Alexandra shows it can result in incredibly dense, congested living environments problematic both for residents and for the state. In Extension 8, some landlords claim their new living environment is deteriorating because of backyard dwellings amongst the RDP houses. However, tenants indicated they had improved their shelter circumstances by moving to this backyard accommodation. In this way, formally constructed freehold housing in well-located areas has directly improved living conditions of its immediate beneficiaries, but has also stimulated the creation of an often lowerquality cheap rental stock. Viewed positively, this represents a gearing of private investment from state investment: the initial expenditure by the state on planning, engineering services, land and housing stimulates multiple privately-funded (and managed) accommodations.

Backyard dwellings also provide a mechanism to densify RDP housing environments typically critiqued for their low residential densities often associated with urban sprawl (see for example Royston, 2003). Increased dwelling and population densities (matched with appropriate infrastructure capacity) provide adequate users for public transport, amenities, services and non-residential activities (Poulsen and Silverman 2005). Ironically, through informal means, backyard dwellings in Extension 8 arguably promote an efficient use of land in a prime site in Johannesburg, contributing to the goals of city compaction, mixed-tenure and intensification often advocated in South Africa (see Development Facilitation Act (Republic of South Africa, 1995, Chapter 1); and the 'National Development Plan 2030' (Presidency, 2012, p. 277), which echo international trends (UN-HABITAT, 2009). These outcomes are also largely in accord with the 'Breaking New Ground' (BNG) housing policy amendment introduced in 2004.

But backyard dwellings can also cause difficulties arising from poorly planned and managed dwellings and infrastructure, particularly in state subsidised low-income neighbourhoods $^{14}$ (see Govender et al., 2010, 2011). Backyard dwellings in RDP 
settlements should not become part of the housing problem. Given the elusive, albeit expanding housing backlog ${ }^{15}$ the state faces, and particularly dire conditions in some existing living environments, a new supply of backyard rental accommodation could be viewed as a welcome addition to the overall stock of housing, even if flawed in the short term.

Backyard dwellings in RDP settlements require state support to function better and to mitigate problems. At present, ambiguous responses emanate from the various spheres of the South African state. Viewpoints vary, particularly at the local scale, where the capacity to monitor, evaluate and to regulate the growth of RDP backyard dwellings can be constrained and is highly influenced by local conditions such as politics and by-laws. So whilst informal backyard shacks are prohibited in some RDP settlements such as Lehae in the south of Johannesburg (Huchzermeyer 2009, p. 65), elsewhere this is not always the case. Such a disjointed position on backyard dwellings may reflect the lack of a national framework to plan for, manage and service the entire backyard rental market.

To date, isolated interventions have channelled state money into improving the quality of the backyard unit. We argue that state intervention should rather focus on spatial planning, adequate infrastructure (supply and design), and on actively (with an incremental approach) encouraging greater dwelling compliance with health and safety norms. We therefore support Lemanski's (2009) contention that the phenomenon should in future be planned for in RDP/BNG housing projects.

\section{Conclusion}

This paper highlights how backyard dwellings fulfil a micro-function in the lives of tenants and landlords within a well-located low-income neighbourhood in Johannesburg. Crucially, backyard dwellings serve as 'life-lines' to diverse urban households and, despite not being an ideal or even accepted mode of accommodation, remains relatively successful. We wish to re-iterate the significant untapped potential existing (and indeed emerging) in RDP/BNG yards. 
In the particular urban renewal context of Alexandra, impacts of this unanticipated phenomenon have yet to be fully realised and pose potential threats to urbanimprovement objectives. The phenomenon also forces an uncomfortable confrontation with 'informality' for a state with ambivalent and ambiguous attitudes to interventions in informal living (see Huchzermeyer, 2009). But through the state-subsided housing programme, coupled with their own initiative and that of tenants, former shack dwellers have become land owners, landlords, and facilitators of accommodation supply, arguably complementing state investment, not undermining it.

The state could in future facilitate the co-production of housing by itself and housing consumers, taking advantage of state control over infrastructure delivery and maintenance and neighbourhood planning to set a much needed framework for backyard dwellings. Along with Bank (2007) and Lemanski (2009) therefore, this paper advocates a supportive strategy for backyard accommodation in South African national housing policy. This approach would broadly accord with the 'encouraging the self-help landlord' approach advocated in UN documentation (UN-HABITAT, 2003, p. 179). RDP housing differs from UN-HABITAT (2003) examples cited in that the primary house is not delivered by the future landlord but by the state. Although this level of government subsidisation is rare in the South, in other contexts self-build initiatives can subsequently attract state or donor-supported infrastructure and tenure investment. The RDP-backyard experience is a reminder of the complex relationship between planned infrastructure delivery and selfbuild: whilst infrastructure provision is often a response to self-build, it can also prompt the emergence of secondary accommodations. Encouraged, planned for and facilitated, this further housing can contribute meaningfully to fulfilling demands for cheap rental accommodation in cities of the South. 


\section{Notes}

${ }^{1}$ Defined here as housing provided outside of formally recognised state processes; and outside of private sector formal housing delivery; i.e. is not incorporated into official, legal land documentation systems and is generally non-compliant with building or zoning regulations.

${ }^{2}$ After the Reconstruction and Development Programme (1994). 'RDP' housing typically refers to a detached or semi-detached house given freely to beneficiaries - with the construction and servicing funded through a state capital subsidy. The release of a new wave of housing policy in 2004 dubbed 'Breaking New Ground' (BNG) (Department of Housing, 2004) orientates housing delivery towards creating sustainable human settlements. Results are mixed however, with problems of distant location, low densities, and few complementary facilities and amenities.

${ }^{3}$ Lemanski (2009, p. 481) refers to RDP homeowners (inclusive of landlords) as "cash-poor [but] asset-rich

${ }^{4}$ Freehold ownership rights were only recognised before 1913, after which the 1913 Native Land Act forced Alexandra residents to lease land from government.

${ }^{5}$ The K206 RDP housing project provides a rare experiment in state built backyard rooms. See ARP (2007).

${ }^{6}$ East Bank and Far East Bank mostly comprise formal extensions of the original township 'Old Alexandra'.

${ }^{7}$ Shacks along London Road and the Jukskei River.

${ }^{8}$ Target households include those either letting backyard space or those living in a backyard dwelling. The researcher attempted to interview at least one household from each block of Extension 8 in order to spread the sample across the settlement.

${ }^{9}$ Most of the respondents' first language was either Zulu or Sotho. Being fluent in the English language only, the field researcher thus relied on her research assistant where translation was necessary.

${ }^{10}$ Pseudonyms are used throughout the paper to protect respondent identities.

${ }^{11}$ These include South African citizenship; monthly household income below R3500 (approximately $\$ 420$ ), evidence of dependents (married/with children). Households who have previously owned property or received a state-subsidized house are ineligible.

${ }^{12}$ This categorisation is restricted to housing features and excludes access to and quality of basic infrastructure (water, sanitation and electricity). Tenants cite virtually no problems in accessing services, mainly attributed to favourable landlord-tenant relationships. 'Quality' is a long-term measure and could not be probed fully in this study given the fairly recent occupation of backyard dwellings in Extension 8.

${ }^{13}$ This is a play on words supporting Kumar's (2003) research in Bangalore and Surat.

${ }^{14}$ Specific threats here relate to poor or below-par building standards (and poorly maintained water and sanitation infrastructure), often impacting on the health of residents. Unanticipated overcrowding through backyard dwellings may further exacerbate the problem (Govender et al, 2011).

${ }^{15}$ Housing backlog estimates in 2010 totalled 2.1 million dwelling units (Minister of Human Settlements, Tokyo Sexwale (2009) cited in Govender et al, 2010, p. 30). 


\section{Acknowledgements}

This paper is based on research in 2010 towards a Bachelor of Science in Urban and Regional Planning (Honours) at Wits University, supported by the National Research Foundation (NRF), South Africa. Any opinion, findings and conclusions or recommendations expressed in this material are those of the authors and therefore the NRF does not accept any liability in regard thereto. The authors wish to thank the ARP, particularly Mr Neels Letter, Mabandla Mwela and Sammy Mamabolo for facilitating site visits and Daluxolo for his research assistance. Thanks also to two anonymous reviewers for their helpful and insightful comments.

\section{References}

Alexandra Renewal Project, (2005). Alex Leader Counters Criticism. Retrieved August 2, 2010, from http:/ www.alexandra.co.za

ARP, (2007). Alexandra's K206 Housing Project. Retrieved February 20, 2010, from http://www.alexandra.co.za/05 housing/article 0612 K206.htm

Beijaard, E.A.W. (1986). 'On Conventillos: Rental Housing in the Centre of La Paz, Bolivia'. Amsterdam, Institute of Cultural Anthropology/Sociology of Development, Free University

Bank, L. (2007). The rhythms of the yards: urbanism, backyards and housing policy in South Africa. Journal of Contemporary African Studies, 25, 205-228

Carey, S. (2009). 'Investigation into the proliferation of low-income private rental housing supply, and the development of recommendations concerning appropriate interventions/ responses'. Prepared for the Social Housing Foundation (SHF) and Urban Landmark (ULM) 
City of Johannesburg, (2012). 'Growth Management Strategy: Growth Trends and Development Indicators Fourth Annual Assessment: Part II: Development Applications'. Johannesburg, Department of Development Planning and Facilitation Crankshaw, O., Gilbert, A., \& Morris, A. (2000). Backyard Soweto. International Journal of Urban and Regional Research, 24, 841-857

Department of Housing (DoH). (2004). 'Breaking new ground: A comprehensive plan for the development of sustainable human settlements'. Pretoria, DoH

Gardner, D. (2010). 'Small-scale Private Rental: A Strategy for Increasing Supply in South Africa'. Report Published for the Social Housing Foundation in conjunction with Urban Landmark

Gilbert, A. (1983). The tenants of self-help housing: Choice and constraint in the housing markets of less developed countries. Development and Change, 14, 449-477

Gilbert, A. and Varley, A. (1989a). From renting to self-help ownership? Residential tenure in urban Mexico since 1940. (In A. Gilbert (Ed.), Housing and Land in Urban Mexico (pp. 13-37). San Diego: Centre for US-Mexican Studies, University of California.)

Gilbert, A., Mabin, A., McCarthy, M. and Watson, V. (1997). Low-income rental housing: are South African cities different? Environment and Urbanisation, 9, 133-147

Gilbert, A. (2008). Slums, tenants and home-ownership: on blindness to the obvious. IPDM, 30, 1-10

Gordon, R., and Nell, M. (2006). 'Small-scale landlords: research findings and recommendations'. Pretoria, Shisaka Development Management Services (Pty) Ltd in Association with CSIR Built Environment

Govender T., Barnes J.M., Pieper C.H. (2010). Housing conditions, sanitation status and 
associated health risks in selected subsidized low-cost housing settlements in Cape Town, South Africa. Habitat International.35, 335-342

Govender, T., Barnes, J. M., and Pieper, C.H. (2011). The Impact of Densification by Means of Informal Shacks in the Backyards of Low-Cost Houses on the Environment and Service Delivery in Cape Town, South Africa. Environmental Health Insights, 5, 23-52

Ha, S-K. (2002). The Urban Poor, Rental Accommodations, and Housing Policy in Korea. Cities. 19, 195-203

Huchzermeyer, M. (2007). Tenement city: the emergence of multi-storey districts through large-scale private landlordism in Nairobi. International Journal of Urban and Regional Research, 31, 714-732

Huchzermeyer, M. (2009). The struggle for in situ upgrading of informal settlements: a reflection on cases in Gauteng. Development Southern Africa, 26, 59-73

Kumar, S. (1989). How poorer groups find accommodation in Third World Cities: A Guide to the Literature. Environment and Urbanization. 1, 71-85

Kumar, S. (1996a). Landlordism in Third World urban low-income settlements: A case for further research. Urban Studies, 33, 753-782

Kumar, S. (1996b). Subsistence and petty capitalist landlords: a theoretical framework for the analysis of landlordism in Third World low income settlements'. International Journal of Urban and Regional Research, 20, 317-329

Kumar, (2003, September). Room for Manoeuvre: Tenure and the Urban Poor in India. (Paper presented at the Second Urban Research Symposium, World Bank Washington, DC, USA)

Kumar, S. (2011). The research-policy dialectic. City: analysis of urban trends, culture, theory, policy, action. 15, 662-673

Lemanski, C. (2009). Augmented informality: South Africa's backyard dwellings as a by-product of formal housing policies. Habitat International, 33, 472-484 
Letter, N. (19 May 2010). Deputy Director, Alexandra Renewal Project, Wynberg, Johannesburg

Morange, M. (2002). Backyard shacks: the relative success of this housing option in Port Elizabeth. Urban Forum, 13, 3-25

Poulsen, L. and Silverman, M. (2005, September). Design strategies for the densification of low income housing. (Paper presented at the World Congress on Housing:

Transforming Housing Environments through Design, Pretoria, South Africa)

Poulsen, L. (2010). A Room in the City: Strategies for Accessing Affordable Accommodation. Urban Forum, 21, 21-36

Presidency of the Republic of South Africa (2012). 'National Development Plan 203:

Our Future - Make it Work'. Prepared by the National Planning Commission.

Rakodi, C. (1995). Rental tenure in cities of developing countries. Urban Studies, 32, $791-811$

Robins, S. (2002). Planning 'suburban bliss' in Joe Slovo Park. Africa: Journal of the International African Institute, 72, 511-548

Royston, L. (2003). On the outskirts: Access to well-located land and integration in PostApartheid human settlement development. (In F. Khan and P. Thring (Eds.), Housing policy and practice in post apartheid South Africa (pp. 234-255). Sandown: Heinemann.) Republic of South Africa (1995). Development Facilitation Act, No 67 of 1995 Social Housing Foundation (SHF) (2008). 'The Supply and Demand of Rental Housing in South Africa'. Johannesburg, SHF and Eighty 20 United Nations Human Settlements Programme (UN-HABITAT) (2003). 'Rental Housing: an essential shelter option for the poor in developing countries'. Nairobi, UN-HABITAT 
UN-HABITAT (2009). 'Global report on human settlements. Planning sustainable settlements'. Nairobi, UN-HABITAT

UN-HABITAT (2011). 'Housing the poor in African cities. Rental housing: a much neglected housing option for the poor. Quick Guide 7: Rental Housing'. Nairobi, UNHABITAT

Watson, V. (1994). Housing policy, subletting and the urban poor, evidence from Cape Town. Urban Forum, 5, 27-43

Watson, V. and McCarthy, M. (1998). Rental Housing Policy and the Role of the Household Rental Sector: Evidence from South Africa. Habitat International, 22, $49-56$

Watson, V. (2009). 'Strategic literature assessment for informal rental research project'. Johannesburg, report for the Social Housing Foundation and Urban LandMark 


\section{Figure and Table Legends}

Figure 1. The context of Alexandra in South Africa and Johannesburg (Prepared by: Alize Le Roux, CSIR Built Environment, 2012)

Figure 2a. Backyard shack in foreground with RDP house in background

Figure 2b. Alternative backyard shacks constructed from wood, brick and plastic

Figure 3a. Izozos arranged in a RDP yard

Figure 3b. An alternative izozo type

Some residents have modified their izozos by adding a patio, burglar bars and or a satellite dish.

Figure 4a. Three backyard rooms arranged in a RDP yard

Electricity connections run between the main dwellings and the backyard rooms.

Figure 4b. Backyard rooms accommodating RDP family members

Here, electricity is internally provided within each backyard room.

Table 1.Summary of backyard dwellings typologies found in Extension 8

\begin{tabular}{|c|c|c|c|}
\hline $\begin{array}{l}\text { Backyard } \\
\text { Dwelling Type }\end{array}$ & $\begin{array}{l}\text { Average tenant } \\
\text { household size }\end{array}$ & $\begin{array}{l}\text { Average } \\
\text { monthly Rent }\end{array}$ & Typical Features $^{12}$ \\
\hline Backyard Shack & 3.6 & $\begin{array}{l}\mathrm{R} 216.67 \\
(\$ 26.00)\end{array}$ & $\begin{array}{l}\text { Mixture of building materials (scrap } \\
\text { metal, wood, corrugated iron, zinc) }\end{array}$ \\
\hline Izozo & 2.5 & $\begin{array}{l}\text { R350.00 } \\
(\$ 42.00)\end{array}$ & $\begin{array}{l}\text { Pre-fabricated, portable structure }\left(6 \mathrm{~m}^{2} \text { - }\right. \\
\left.9 \mathrm{~m}^{2}\right) \text { made of corrugated iron with } \\
\text { wooden doors, window frames and } \\
\text { cement flooring. Assembled in pieces, } \\
\text { ranging in price from } \mathrm{R} 2500-\mathrm{R} 3000 \\
\text { (equivalent of } \$ 300-\$ 360) \text { per unit }\end{array}$ \\
\hline Backyard Room & 3 & R650 (\$78.00) & $\begin{array}{l}\text { Closest resemblance to RDP housing in } \\
\text { terms of the types and quality of housing } \\
\text { materials used - block or brick walls, } \\
\text { corrugated iron roof. The proportion of } \\
\text { rooms to backyard shacks and izozos is } \\
\text { very low. }\end{array}$ \\
\hline
\end{tabular}

